Boston University School of Law Scholarly Commons at Boston University School of Law

Faculty Scholarship

6-2013

\title{
The Baby and the Bath Water: The American Critique of European Contract Law
}

Daniela Caruso

Boston University School of Law

Follow this and additional works at: https://scholarship.law.bu.edu/faculty_scholarship

Part of the Contracts Commons, and the European Law Commons

\section{Recommended Citation}

Daniela Caruso, The Baby and the Bath Water: The American Critique of European Contract Law, No. 12-43 Boston University School of Law, Public Law Research Paper (2013).

Available at: https://scholarship.law.bu.edu/faculty_scholarship/68 


\section{BU School of Law}

\section{THE BABY AND THE BATH WATER: The AmERICAN Critique OF EUROPEAN Contract LAW}

Forthcoming 61:3 American Journal of Comparative Law 2013

Postnational Rulemaking between Authority and Autonomy Conference, Amsterdam,

September 20-21, 2012

Boston University School of Law Working Paper No. 12-43

(August 24, 2012, Rev. June 21, 2013)

Daniela Caruso

Boston University School of Law

This paper can be downloaded without charge at:

http://www.bu.edu/law/faculty/scholarship/workingpapers/2012.html 


\section{DANIELA CARUSO*}

The Baby and the Bath Water: The American Critique of European Contract Law ${ }^{* *}$

61 American Journal of Comparative Law 479 (2013)

This paper aims to contribute to a larger research agenda concerning the possibility of meaningful transatlantic dialogue about private-law reform. Both the European Union and the United States regulate private autonomy extensively. In spite of contextual similarities, however, there are several barriers making dialogue among legal scholars difficult. In particular, the conversation about social justice-by now an important element of private-law reform within the European Union-is less prominent in American contract law scholarship. In U.S. legal academia, social justice is a matter for moral philosophers, development economists, and constitutionalists, and also provides normative frameworks for current property and torts debates, but its impact on contracts scholarship has declined over the past few years, and efficiency discourse has often replaced social justice parlance.

Against this background, this paper takes a close look at a recent transatlantic exchange in matters of private-law reform-a Chicago Law School conference on a proposed Common European Sales Law-and identifies a few counter-intuitive points of convergence between U.S. and European scholarship. Along the way, the paper also highlights structural and discursive incompatibilities, but concludes that the dialogue is, as a whole, valuable and should be kept alive.

In designing post-national rules for private autonomy, Europe may draw better lessons from U.S. regulatory experiences if it first deconstructs the wholesale pro-market rhetoric of otherwise relevant literature. When this is done, the payoffs of American commentaries become more appreciable. Taking the lead from some Chicagoan insights, this paper recommends customizing the empirical investigation of EU markets so as to factor socio-economic asymmetries into the equation of private-law reform.

\footnotetext{
${ }^{*}$ Professor of Law, Boston University School of Law.

** Paper presented at the Conference at the University of Amsterdam: The Architecture of Postnational Rulemaking between Authority and Autonomy (Sept. 20-21, 2012). Thanks to James Fleming, Miles Freeman, Martijn Hesselink, Duncan Kennedy, Chantal Mak, Fionnuala Ní Aoláin, and Fernanda Nicola for comments on earlier versions of this draft. Errors remain mine.
} 


\section{INTRODUCTION}

This paper aims to contribute to a larger research agenda concerning the possibility of meaningful transatlantic dialogue about private-law reform. ${ }^{1}$ Both the European Union and the United States currently exert considerable effort in regulating private actor behavior. Ongoing reforms address contractual dealings between merchants and buyers of goods or services (often individual consumers); and many of the new rules are meant to be enforced through private litigation against the breaching party (usually a merchant). Andrei Shleifer's convenient taxonomy defines this enforcement of public rules via private litigation as an intermediate regulatory step between untrammeled autonomy and regulation via agency enforcement. ${ }^{2}$ The ideologically nuanced character of this technique, half-way between top-down control and laissez-faire, makes it politically more viable than stricter regulatory alternatives in response to the ongoing global crisis. As a result, on both sides of the Atlantic we are witnessing new efforts to redefine the rules of private autonomy in such markets as credit cards or online sales.

In spite of contextual similarities, however, there are barriers making dialogue among legal scholars difficult. In particular, the conversation about social justice, which in the European Union has grown into an important element of private-law reform, ${ }^{3}$ is now less prominent in American contract law scholarship. In American legal academia, social justice is now a matter for moral philosophers, ${ }^{4}$ development economists, ${ }^{5}$ and constitutionalists, ${ }^{6}$ and also provides normative frameworks for current property and torts debates, but its impact on contracts scholarship has significantly declined. To be sure, the U.S. debate about contract rules is not exempt from worries about unfair commercial practices and systemic distributive asymmetries, ${ }^{7}$ but the methodology for addressing such phenomena has been, for a few years, more frequently informed by neoclassical

\footnotetext{
${ }^{1}$ See Fernanda Nicola, Transatlanticisms: Constitutional Asymmetry and Selective Reception of U.S. Law and Economics in the Formation of European Private Law, 16 CARDOZO J. INT'L \& COMP. L. 87 (2008).

${ }^{2}$ Andrei Shleifer, Understanding Regulation, 11 EuR. Fin. MGMT. 439, 445 (2005).

${ }^{3}$ See Chantal Mak, Constitutional Aspects of a European Civil Code, in TowARDS A EUROPEAN CIVIL CODE 333, 349 (Hartkamp et al. eds., 4th ed. 2011) (“[T]he discussion on further harmonization of private law can explicitly consider the role of private law in the redistribution of wealth in society. ... [Private law] represents a view on how society should be arranged and what values govern the relationships among European citizens.") (footnotes omitted).

${ }^{4}$ See, e.g., Martha C. Nussbaum, SeX and Social Justice (1999); John Rawls, A Theory of Justice (1971).

${ }^{5}$ See, e.g., AMARTya SEN, INEQUALITy REEXAMined (1992).

${ }^{6}$ See, e.g., Frank Michelman's legal scholarship on social justice, as highlighted by Judge Guido Calabresi, In Tribute: Frank I. Michelman, 125 HARV. L. REV. 879 (2012).

${ }^{7}$ See, e.g., Rachel Arnow-Richman, Cubewrap Contracts: The Rise of Delayed Term, Standard Form

Employment Agreements, 49 ARIZ. L. REV. 637 (2007).
} 
parameters and over-determined by efficiency concerns. ${ }^{8}$ In Europe, efficiency and private autonomy also remain fundamental metrics among contracts scholars, ${ }^{9}$ but given the political dynamics of legal integration over the past three decades, the proponents of contract law harmonization have had to provide frequent reassurance that the harmonization of market rules would not ignore the justice aspirations of Member States' private laws. As a result, social justice has gained discursive ground in EU contract law.

Against this background, this paper takes a close look at a recent transatlantic exchange in matters of private-law reform-a Chicago Law School conference on a proposed Common European Sales Law (CESL) ${ }^{10}$ — and identifies a few counter-intuitive points of convergence between U.S. and European scholarship. Along the way, the paper also highlights structural and discursive incompatibilities, but concludes that the dialogue is, as a whole, valuable and should be kept alive.

In commenting on the proposed CESL, U.S. scholars offer a reflection of the multitude of opinions that animate the current American debate on the regulation of private autonomy. The challenge for European readers is to understand where each critique comes from, to eliminate argumentative postures determined by contingent American politics, and to adapt what remains to the different reality of European law and politics. Reading between the lines is often necessary. There may be more support in U.S. legal academia for an ethical, embedded and socially sensitive market regime than first meets the eye. There may be important caveats and lessons underneath a patina of neoliberal rhetoric.

The proposed CESL is meant to be an optional instrument, i.e., a sales regime that parties may choose by agreement instead of default rules resulting from state law and international private law. Some of the American commentary questions the wisdom of adding yet another regime to those already available. ${ }^{11}$ Other contributions focus instead, in whole or in part, on the substantive aspects of the CESL, namely on the particular

\footnotetext{
${ }^{8}$ See, e.g., Russell B. Korobkin, Bounded Rationality, Standard Form Contracts, and Unconscionability, 70 U. CHI. L. REV. (2003).

${ }^{9}$ See, e.g., Simon J Whittaker, The Optional Instrument of European Contract Law and Freedom of Contract, 7 Eur. Rev. ConT. L. 371 (2011).

${ }^{10}$ Conference on European Contract Law at the University of Chicago Law School: A Law-and-Economics Perspective (Apr. 27-28, 2012), available at http://www.law.uchicago.edu/events/europeancontractlaw [hereinafter the Chicago Conference]. The conference papers have been revised and published. See Thomas Ackermann, Introductory Note, 50 Common MKT. L. REV. Special Issue 1 (2013).

${ }^{11}$ See, e.g., Saul Levmore, Harmonization, Preferences, and the Calculus of Consent in Commercial and Other Law, 50 Common MKт. L. Rev. Special Issue 243 (2013); Eric Posner, The Questionable Basis of the Common European Sales Law: The Role of an Optional Instrument in Jurisdictional Competition, 50 COMMON MKT. L. REV. Special Issue 261, 270-271 (2013) (noting that the pro-consumer rules of the CESL make it unattractive to sellers and therefore unlikely to succeed as an opt-in device).
} 
balance that the proposed text strikes between the parties' private autonomy and competing regulatory goals. This paper examines only the latter, substantive set of critiques, in light of the fact that the optional CESL regime may one day serve as blueprint for a supranational law of contract. ${ }^{12}$ Its content-in so far as it endorses a particular blend of autonomy and regulation-may therefore matter more than its current institutional status.

Most of the contributions referenced within this paper are critical of the proposed CESL. Predictably, American scholars conclude that the proposal interferes excessively with private autonomy; that its analytics of consumer protection are obsolete; that it leads to inefficient results; and that it does not even promote fairness. This condemnation of the Commission's work, however, comes in several strands that this paper attempts to disentangle. First, there is a typically neoclassical critique, which begins with the tenets of price theory and ends with a negative assessment of the Commission's entire involvement in contract law matters. Professor Richard Epstein's paper offers the most prominent example of such a perspective. ${ }^{13}$ This approach still sets the tone of the discussion on contract rules in U.S. academic circles and deserves assessment.

There is, second, a line of attack grounded in UCC studies that probes the Commission's understanding of norm formation in business communities. Professor Lisa Bernstein, an authority in this field, manages to touch, perhaps inadvertently, on a highly sensitive point of disagreement among EU academics-namely, the questionable wisdom of assuming the existence of a collective and coherent ethos at the heart of the internal market project. ${ }^{14}$

A third type of critique shares Bernstein's skepticism and follows the methodology of behavioral law and economics. It is notable, in this regard, that the proposed CESL is disliked not only by law-and-economics scholars traditionally averse to market regulation, but also by academics who have actively promoted regulatory agendas in response to the recent financial crisis. The contribution co-authored by

\footnotetext{
${ }^{12}$ See Thomas Ackermann, Public Supply of Optional Standardized Consumer Contracts: A Rationale for the Common European Sales Law? 50 Common MKT. L. Rev. Special Issue 11, 12 (2013) (reminding his audience that the CESL, just like many other instruments of private law approximation, has its origin in a well documented project of substantive contract law codification at the supranational level. Because of political resistance, this project has had to morph into diluted and pluralistic forms of harmonization, but intermediate steps such as the CESL still bring the European Union a little closer to a uniform and supranational contract law).

${ }^{13}$ Richard Epstein, Harmonization, Heterogeneity and Regulation: CESL, The Lost Opportunity for Constructive Harmonization, 50 CommON MKT. L. REV. Special Issue 207 (2013).

${ }^{14}$ Lisa Bernstein, An (Un)Common Frame of Reference: An American Perspective on the Jurisprudence of the CESL, 50 Common MKT. L. REV. Special Issue 169 (2013).
} 
Professors Omri Ben-Shahar and Oren Bar-Gill proves very instructive in this regard and will be discussed extensively. ${ }^{15}$

To explain these authors' negative tone, which is so loud at times as to silence what is in fact constructive criticism, these pages address the narrow and defensive stance of those behavioral economists who happen to support regulatory agendas in the context of American legal reforms. Their caution is a necessary adaptation to a currently dominant mode of American legal and economic thought that assumes the inherent efficiency of markets and holds pro-consumer rules to prohibitively high justificatory standards. This mode of discourse, however, is neither immanent nor universal. Evidence of its historical contingency in American contracts scholarship should allow us to relax its assumptions and to witness more fruitful dialogue between U.S. behavioral scholarship and EU private-law projects. In designing a post-national architecture of autonomy - its scope, its limits, its practical workings-Europe may draw better lessons from U.S. regulatory experiences if it first deconstructs the wholesale pro-market rhetoric of otherwise relevant literature. When this is done, the payoffs of American commentaries become more appreciable.

The last part of this paper is about such payoffs. The emphasis of behavioral law and economics on market-specific dynamics is a call for clarity about the uneven distributive impact of a uniform, coherent and cross-sector EU private law. It is with this type of insight that EU lawmakers and academics should engage.

The U.S.-based behavioral critique is, at its heart, an invitation to bring to the table of private-law harmonization a whole set of currently missing data. Its emphasis on consumer biases, irrational choices, and path dependence should prompt research on aspects of the EU market that are to this day severely understudied. Research should focus, in particular, on those market behaviors that reinforce the socio-economic asymmetry between "center" and "periphery" in Europe. ${ }^{16}$ To name just one example, the resilient dominance of Western brands' reputation in the perception of Central and Eastern European consumers is irrational, and yet strong enough to grant Western manufacturers long-lasting advantages. Strangely, such phenomena are not on the radar screen of the European Commission, whose current market studies yield mostly

\footnotetext{
${ }^{15}$ Oren Bar-Gill \& Omri Ben-Shahar, Regulatory Techniques in Consumer Protection: A Critique of European Consumer Contract Law, 50 Common MKT. L. REv. Special Issue 109 (2013) [hereinafter Regulatory Techniques].

${ }^{16}$ Damjan Kukovec, A Critique of the Rhetoric of Common Interest in the European Union Legal Discourse (Harv. Law Sch. Inst. for Global Law \& Pol'y., Working Paper, 2012), available at http://www.harvardiglp.org/new-thinking-new-writing/a-critique-of-rhetoric/ (developing fundamental analytics for the study of center-periphery asymmetries in EU law). See also R.L. King, Southern Europe: Dependency or Development?, 67 GEOGRAPHY 221 (1982) (adapting the "core-periphery framework" to the regional development of Europe).
} 
aggregate data and fail to grasp the impact of proposed uniform rules upon structurally disadvantaged merchants. Ultimately, this paper recommends customizing the empirical investigation of EU markets so as to factor socio-economic asymmetries into the equation of private-law reform.

\section{THE CHICAGO CONFERENCE IN CONTEXT}

As a general matter, U.S. scholars tend to take notice of Continental legal developments when these developments play into a current obsession within American jurisprudence. At the time of the federalist revolution wrought by the Rehnquist Court, U.S. law reviews witnessed a flurry of writings on such topics as European legal integration, subsidiarity, and multi-level governance. ${ }^{17}$ The EU's ongoing project of legal integration had immediate pay-offs for the scholars of U.S. federalism: it provided an opportunity to discuss politically salient domestic affairs in a context that was foreign and different enough to dilute ideological bias; it conferred a veneer of scholarly objectivity; and it showed that enhancing or preserving states' autonomy was not necessarily a conservative project. ${ }^{18}$

The current surge of interest in EU sales law is equally due to an overlap between positive EU law and a pressing reform agenda in the United States. The regulation of private autonomy-its extent and indeed its very existence-is all the rage in contemporary U.S. politics. The Consumer Financial Protection Bureau (CFPB), which began operating in the summer of 2012 in the face of strenuous political opposition, was allegedly the brainchild of two prominent law professors who had laid the theoretical grounds for enhanced consumer credit regulation. ${ }^{19}$ In this context, the American commentary on the proposed CESL is more than academic. Arguments matter. The determined defense of freedom to and from contract was the cornerstone of judicial and legislative assaults upon President Obama's health care reform—a piece of legislation

\footnotetext{
${ }^{17}$ See, e.g., George Bermann, Taking Subsidiarity Seriously: Federalism in the European Community and the United States, 94 Colum. L. Rev. 332 (1994); Ernest Young, Preserving Member State Autonomy in the European Union: Some Cautionary Tales from American Federalism, 77 N.Y.U. L. REV. 1612 (2002).

${ }^{18}$ Daniela Caruso, EU Law in U.S. Legal Academia, 20 TUL. J. INT’L \& CoMP. L. 175 (2011). Similarly instrumental to self-reflections were the forays into Continental private law of the 1980s: the inquiry into the efficiency of common law rules - an early spring-board for the phenomenal diffusion of law and economics in U.S. legal academia-found experiential validation and intellectual legitimacy in the control group of alternative legal systems. Another strand of U.S. scholarship, known as the corporate governance movement, found both food for thought and important quantitative evidence in diverse European regimes of executive compensation, share-holders' rights, and corporate social responsibility.

${ }^{19}$ Oren Bar-Gill \& Elizabeth Warren, Making Credit Safer, 157 U. PA. L. Rev. 1 (2008); see also Jared Elosta, Dynamic Federalism and Consumer Financial Protection: How the Dodd-Frank Act Changes the Preemption Debate, 89 N.C. L. REV. 1273 ("Adopting the idea of Bar-Gill and Warren, Dodd-Frank created the Consumer Financial Protection Bureau[,] whose mission is to ensure 'that markets for consumer financial products and services are fair, transparent, and competitive.”') (internal citations omitted).
} 
whose enactment, in whole or in part, brings about massive reallocations of private and public money. Since 2008 - the conventional onset of the U.S. (and global) financial crisis-American legal and political reflections have been dominated by one overarching set of questions: why, how, and to what extent to regulate private autonomy.

The proverbial American faith in untrammeled individual initiative has indeed been shaken by the economic downturn. It is by now established that under- and deregulation allowed for an unprecedented degree of disconnect between financial markets and more tangible assets of the global economy; it is also commonly accepted that the liberalization of mortgage policies led to the bursting of the housing bubble. ${ }^{20}$ But beyond this basic core of agreement, opinions diverge widely about how to prevent this series of unfortunate events from re-occurring. In the sphere of politics, as always, matters play out rather simplistically: conservatives cling to different varieties of laissez-faire ideology and point to the Euro-Crisis as yet another example of regulatory failure; liberals, in turn, invoke the need for tougher market rules and look at Europe's parallel regulatory initiatives for inspiration. In the arena of legal academia, by contrast, the game is nuanced and subtle. It is in this arena that the EU Commission, by launching its "optional tool," unwittingly provided U.S. legal scholars with a fresh opportunity to test their analytical models and to take them to a higher level of abstraction. The Chicago conference could deal with the regulation of private autonomy in another continent, and therefore in a less heated or consequential fashion.

Every regulatory project of the European Union is cause for concern in the United States. The regulation of technical or safety standards may result in trade barriers for American products; privacy rules impose constraints upon commercial practices of U.S. exporters; services regulation, especially in the financial sector, may foreclose highly profitable avenues for U.S.-based banking, insurance and investment. Most importantly, the adoption of strict regulatory models by the European Union-a major trade bloc-is so prominent on the world scene as to raise questions about alternative, and often more relaxed, arrangements on the other side of the Atlantic. ${ }^{21}$ Consumer protection-an incidental goal of the $\mathrm{CESL}^{22}$ - is one aspect of regulation that is subject to close monitoring in the United States. This field of EU action was notably shaped by American

\footnotetext{
${ }^{20}$ See, e.g., Joseph Stiglitz, Reversal of Fortune, 50 VANITY FAIR 134 (2008); Joseph Stiglitz, The Book of Jobs, 54 VANITY FAIR 34 (2012) (explaining the crisis, in large part, as a consequence of the nonregulation of financial and housing markets since the 1980s).

${ }^{21}$ Francesca Bignami, Cooperative Legalism and the Non-Americanization of European Regulatory Styles: The Case of Data Privacy, 59 AM. J. ComP. L. 411 (2011).

${ }^{22}$ See Simon Whittaker, Identifying Legal Costs of Operation of the Common European Sales Law, 50 COMmon MkT. L. Rev. Special Issue 85 (2013) (emphasizing that the CESL's primary goal is the facilitation of cross-border trade).
} 
archetypes at its dawn, ${ }^{23}$ but it soon developed its own structure and philosophy. When EU lawmakers enact pro-consumer measures that diverge from those prevalent, at any given time, on American soil, U.S. observers tend to remark upon the superiority of their own (often less intrusive) regulatory mechanisms. When the EEC product liability directive was adopted, for instance, the U.S. scholars who were arguing for the demise of strict liability in the Restatement Third of Torts: Products Liability, took the trouble to criticize the European choice as theoretically ill-conceived and indifferent to empirical evidence. $^{24}$

The CESL proposal has prompted similar reactions in U.S. legal academia. The proposal imposes a number of limits upon private autonomy and explicitly protects consumers from aggressive business practices. It is, therefore, a typical project of EU regulation that embodies a higher degree of paternalism than its American counterpart. ${ }^{25}$ U.S. critics have predictably begun to take the proposal apart, this time with perhaps particularly high energy and enthusiasm. ${ }^{26}$

\section{The Neo-Classical CRitique of the CESL Proposal}

The question whether the harmonization of private law by means of EU legislation should embrace the goal of social justice has been answered, by many Europeans and some foreign observers, in the affirmative. ${ }^{27}$ In typical old-continent fashion, this answer has been grounded in political, historical, and philosophical arguments. In support of this choice, authors have invoked the expressive function of

${ }^{23}$ See Michelle Everson, Legal Constructions of the Consumer, in KNOWIng CONSUMERS: Actors, IMAGES, IDENTITIES IN MODERN HistORY (Gerhard Haupt \& Frank Trentmann eds., 2005) (noticing how a 1962 speech by John F. Kennedy concerning the thalidomide crisis provided content for an EEC Council Resolution on a "Preliminary Programme for a Consumer Protection and Information Policy" (Council Resolution, 1975 O.J. (C 92) 1)).

${ }^{24}$ James A. Henderson, Jr. \& Aaron D. Twerski, What Europe, Japan, and Other Countries can Learn from the American Restatement of Products Liability, 34 TEX. INT'L L.J. 1, 12-13 (1999) (“The self-proclaimed progression from negligence to strict liability in Europe and Japan is quintessentially 1960s American rhetoric. The movement in this country over the last three decades has been in quite the opposite direction.") Similar criticism poured on the prohibition of many forms of distribution agreements under Article 85 of the EEC Treaty (now TFEU Art. 101) in the context of EU competition law.

${ }^{25}$ With many qualifications, the closest American analogy to a uniform sales regime for Europe would be the Uniform Commercial Code, which contains both mandatory rules and sticky default rules in favor of buyers.

${ }^{26}$ The Conference on European Contract Law was held at a top U.S. law school, and the CESL underwent detailed commentary by highly esteemed contracts scholars. A tribute of this magnitude to the ongoing work of European academics and bureaucrats probably means that the CESL has touched a nerve or two. See Omri Ben-Shahar, Introduction: A Law and Economics Approach to European Contract Law, 50 COMMON MKT. L. ReV. Special Issue 3 (2013).

${ }^{27}$ Gert Brueggemeier et al., Study Group on Social Justice in European Private Law, Social Justice in European Contract Law: A Manifesto, 10 EUR. L.J. 653 (2004). 
private-law codifications in continental history, the importance of regulating transactions between private actors in a way that reflects higher commitments of the polity, etc. ${ }^{28}$ This stance, while still vigorously contested, has gained sufficient ground in EU politics to make it difficult for the Commission to enact private-law instruments that would exclusively pursue the goal of market efficiency. More fundamentally, the Commission is constrained by the historical fact that for at least one century the private laws of the Member States have been embracing, to various degrees, redistributive considerations. ${ }^{29}$ The Commission's slate is by no means blank. It simply lacks the power to reinstate a neoclassical, discrete model of private law that is indifferent to such values as the protection of the weaker party. Further constraints come from the important role of consumer protection as a source of legitimacy for supranational intervention in privatelaw matters, and from the coarse assumption that, in business-to-consumer contracts, consumers are weaker than traders. As a result, if the Commission wants to forge ahead with its private-law agenda, it has to do so in a way that responds at least in part to social justice considerations and that constrains private autonomy in consumer transactions.

Some U.S. commentators simply miss the point of such institutional limitations when they assail the Commission's proposal with neoclassical critiques. ${ }^{30}$ These authors end up opposing just about any form of interference with private autonomy and repeatedly point out that the costs due to traders' increased liability will be passed along to consumers in the form of higher prices. This stance is based not on the belief that the market has no failures, but rather on the assumption that the market itself will, with time, produce endogenous cures for its own pathologies-be they misinformation of consumers, abuses of dominance, or insufficiently safe products. ${ }^{31}$ Traders will compete for customers by improving both products and sales terms, until an optimal equilibrium is established. Common law courts play an important role in this holistic scenario by enforcing privately negotiated agreements as well as tort rules. ${ }^{32}$ By contrast, the legislative preemption of private autonomy, with rare exceptions, interferes with the market's natural self-healing process and is therefore to be avoided like a toxic chemical in organic gardens. Richard Epstein, denouncing the Commission's "relentless statism" and "bureaucratic ambitions," expressed this line of thought in stark terms: "[S]o long as the European Commission believes that freedom of contract is the preferred solution, it

\footnotetext{
${ }^{28}$ See, e.g., Hugh Collins, The European Civil Code: The Way Forward (2008); Duncan Kennedy, The Political Stakes in "Merely Technical” Issues of Contract Law, 1 EUR. REV. PrIV. L. 7 (2001).

${ }^{29}$ Hans-W. Micklitz, Introduction-Social Justice and Access Justice in Private Law, in THE MANY CONCEPTS OF SOCIAL Justice IN EuropeAn Private LAW 1, 3 (Hans-W. Micklitz ed., 2011).

${ }^{30}$ See Epstein, supra note 13.

${ }^{31}$ Richard A. Epstein, Behavioral Economics: Human Errors and Market Corrections, 73 U. CHI. L. REV. 111, 111 (2006).

32 Ronald Coase, The Problem of Social Cost, 3 J.L. \& ECON. 1 (1960); Richard Posner, A Theory of Negligence, 1 J. LEGAL STUD. 29 (1972).
} 
should do what all sound regulators do to achieve that goal: step out of the limelight as quickly as possible.” 33

Within this divisive framework, the chances of a fruitful U.S.-EU dialogue are practically zero. The Commission is indeed committed to going forward with the harmonization of private law and, as a rational institutional player, is definitely moved by the self-serving goal of expanding the EU's role in private-law matters. ${ }^{34}$ It is equally set in stone that consumer protection is part of the Commission's agenda and that, given the legacy of Member States' private laws, the sheer maximization of social welfare-with no regard for its distribution among categories of contractual parties - cannot be the guiding criterion for EU action. Along these lines, Professor Mak aptly rebutted Epstein's critique in Chicago by pointing at the legal-political context of the CESL (as opposed to the merely economic U.S. perspective). ${ }^{35}$ Still, the gap between the two perspectives is just too wide to fill.

More can be made, however, of the comments of scholars who take the general approach of the CESL for granted, and only question whether the particular means chosen by the drafters to produce social-justice inspired results really make sense. Among these scholars is Lisa Bernstein.

In neoclassical style, Professor Bernstein's work has explored the ability and willingness of traders to self-regulate, without need to resort to state-provided rules or courts. She has focused especially on communities of traders kept together by such powerful links as religion, identity, and culture. ${ }^{36}$ Her findings, grounded in empirical studies, yield a radical critique of Karl Llewellyn's “incorporation strategy." The Uniform Commercial Code-Llewellyn's brainchild-assumes the existence of immanent business norms and adopts legal standards (such as "usage of trade") designed expressly to receive and enforce such norms. By Bernstein's account, however, no consistent usage really exists that is coterminous with any given trade as a whole; smaller communities may at best harness weak norms from custom, but even these norms, while perhaps initially helpful, are soon replaced by transaction-specific course of dealing. ${ }^{37}$ Hence, merchants resent having to submit to legal assessments that may be detached from

\footnotetext{
${ }^{33}$ Epstein, supra note 13.

${ }^{34}$ See Nicolas JabKo, Playing the Market: A Political Strategy for Uniting Europe, 1985-2005 (2006).

${ }^{35}$ Chantal Mak, Unweaving the CESL: Legal-Economic Reason and institutional Imagination in European Contract Law, 50 Common MKT. L. ReV. Special Issue 277, 286-294 (2013).

${ }^{36}$ Lisa Bernstein, Opting Out of the Legal System: Extralegal Contractual Relations in the Diamond Industry, 21 J. LEGAL STUD. 115 (1992).

${ }^{37}$ Lisa Bernstein, The Questionable Empirical Basis of Article 2's Incorporation Strategy: A Preliminary Study, 66 U. CHI. L. REV. 76 (1999).
} 
their intended deals. To Bernstein, the CESL's frequent recourse to social norm incorporation is anathema. If the incorporation technique does not work even where all the preconditions for the emergence of common trade ethics subsist, how could it possibly function in a market as diverse and inchoate as the European Union?

Professor Bernstein's work is well known to EU scholars of self-regulation in European contract law. ${ }^{38}$ Self-regulation by professional bodies has proven successful in certain areas of the European market and has been the Commission's saving grace in matters of harmonization of technical standards since 1985. But when the harmonization of contract law is at stake, Bernstein's stance may become anathema itself. General clauses and incorporation techniques abound in existing civil codes and would be essential to the passing of uniform laws because they would allow for judicial discretion in national courts. Once again, it would be impossible, given the institutional boundaries of private-law harmonization, to please all relevant constituencies without periodic reference to local norms (in the CESL proposal variously named "good commercial practice" or "good faith and fair dealing” or simply "usage”). In fact, such incorporation clauses would be the lynchpin of institutional balance in a Europe with harmonized contract laws, and as such, they have been vigorously endorsed in legal scholarship. ${ }^{39}$ Just as with Epstein's contribution, the clash between U.S. scholarly critique and EU institutional constraints leaves one with a sense of dialectical gridlock. This time, however, the Chicagoan critique contains helpful hints for continuing dialogue. To be treasured in Bernstein's work is the call for a closer understanding of European markets. As we shall see, the CESL and the entire project of private-law harmonization should not ignore Chicago's fundamental question-namely, whether common assumptions about such diverse socio-economic realities as those at the center and at the periphery of the Union are at all realistic. Bernstein frames the question as an empirical one, but the answer, for better or worse, requires more than just empirical work.

\section{THE CESL AND BEHAVIORAL LAW AND ECONOMICS}

A central contribution to the Chicago conference came from Professors Bar-Gill and Ben-Shahar. ${ }^{40}$ They share a basic faith in the tenets of classical law and economicsmost noticeably in the self-healing properties of most markets. Both have made important contributions in the field of behavioral law and economics by collecting empirical data on

${ }^{38}$ See Fabrizio Cafaggi, Private Regulation in European Private Law, in TowARDS A EUROPEAN CiviL CODE, supra note 3, at 91 .

${ }^{39}$ See, e.g., Martijn Hesselink, The Concept of Good Faith, in TOWARDS A EUROPEAN CIVIL CodE 471 (Hartkamp et al. eds., 3d ed. 2004).

${ }^{40}$ Regulatory Techniques, supra note 15. 
the relative rationality of market players and by testing the workability of theoretical models. For these authors, the theoretical predictions of classical law and economics give way to regulatory mechanisms only in cases of documented and persistent market failures. The burden of proof rests on data collectors: laws should be shaped upon the theoretical predictions of neoclassical economics unless and until evidence falsifies or complicates such predictions.

Omri Ben-Shahar is the Chicago Law School faculty member who hosted the conference devoted to the CESL. An important element of his rich scholarly agenda is the project of busting the "myths of consumer protection." ${ }^{41}$ His work has centered on identifying market mechanisms that can bring about fairness in consumer transactions, thereby rendering government regulation pointless. ${ }^{42}$ He has also authored a scathing critique of traditional disclosure mandates, showing that they are useless (or worse, harmful) as tools of consumer protection law. ${ }^{43}$ His critique of mandated disclosure as we know it, however, is occasionally coupled with regulatory prescriptions. These include the restriction of autonomy in consumer transactions whose intrinsic riskiness cannot be cured by enhanced information. ${ }^{44}$

Oren Bar-Gill's academic training and success in U.S. legal academia are in many ways similar to his co-author's. However, he has espoused the cause of governmental regulation more visibly. Focusing on consumer credit, he has argued for the creation of a federal agency that would oversee consumers' access to financial products. ${ }^{45}$ To be sure, Bar-Gill's arguments in favor of regulation have always been drawn narrowly and supported by quantitative and qualitative evidence in very specific contexts. His passionate case for what is now the CFPB was utterly and avowedly post-empirical.

To scholars of this persuasion, the Commission's work on the harmonization of European contract law is bound to appear ill-conceived at its core. On one hand, it contains long lists of mandatory rules, including a plethora of disclosure duties; on the other, it bunches up into one large category a very diverse set of consumers, making it impossible to justify any of its autonomy-thwarting provisions upon empirical and

${ }^{41}$ Omri Ben-Shahar, One Way Contracts: Consumer Protection without Law, 6 EUR. REv. ConT. L. 221 (2010).

${ }^{42}$ See Omri Ben-Shahar \& Kyle D. Logue, Outsourcing Regulation: How Insurance Reduces Moral Hazard, 111 Mich. L. REV. 197 (2012).

${ }^{43}$ Omri Ben-Shahar \& Carl Schneider, The Failure of Mandated Disclosure, 159 U. PENN. L. Rev. 647 (2011).

${ }^{44}$ See id. at 748 ("Sometimes advice . . . will not adequately help the naïve in their dealings with the sophisticated .... A more aggressive way to use the law to help the naïve is to outlaw practices that are too likely to result in disaster.").

${ }^{45}$ See Bar-Gill \& Warren, supra note 19, at 2 ("We [urge] the creation of a new federal regulator that will have both the authority and the incentives to police the safety of consumer credit products.”). 
context-specific data. The authors do acknowledge the CESL's peculiar legal nature-a uniform law that would trump the variety of state laws only if chosen by the parties to each transaction, and would coexist with both more and less intrusive sales laws in all the Member States. Indeed, an important aspect of their objections is the foreseeably awkward interplay between the CESL and background state laws. Most of their critique, however, focuses on the CESL per se, as if it were a uniform law proposal of the UCC type, subject to the opt-in of state legislators—not just individual market actors. There are several key articulations in their argument.

The first and most predictable line of attack stems directly from price theory: leaving sellers little wiggle room in the design of choice of forum, exculpatory clauses and limitation of remedies will necessarily lead to price increases and hurt the very consumers whom regulation intended to protect: "The ex post pro-consumer arrangements will be priced ex ante. Consumers will thus pay for protections that many of them would rather waive for a discount." ${ }^{, 46}$

So far, the argument resembles a well-rehearsed line (the pass-along critique) which also animates the paper by Richard Epstein discussed above. Epstein's blanket aversion to mandatory clauses and black lists is, however, rather extreme, and it is not fully shared by these authors, one of whom, as we have seen, has been actively involved in a major pro-consumer reform. In the Bar-Gill and Ben-Shahar paper, the price increase allegedly due to the CESL's regulatory content comes under attack not so much on efficiency grounds, but along distributive lines:

This price effect is particularly disturbing when it is regressive-namely, when all consumers pay for what only the more sophisticated ones enjoy. Ironically, when the price effect is regressive, a wholesale inclusion of mandatory terms undermines rather than promotes, "social justice" concerns, which intend to protect weaker consumers and secure their access to the markets. ${ }^{47}$

The idea that mandatory clauses in consumer contracts would have perverse redistributive effects, penalizing the neediest of consumers, has a long pedigree in U.S. legal scholarship. It has often been applied in the context of habitability warranties in landlord-tenant agreements, deemed regressive by "mainstream" scholars because they make rentals too costly for the poor. ${ }^{48}$ Thanks to popular vignettes ${ }^{49}$ and to its alluring

\footnotetext{
${ }^{46}$ Regulatory Techniques, supra note 15, at 110.

${ }^{47} I d$. (footnote omitted).

${ }^{48}$ See, e.g., Charles J. Meyers, The Covenant of Habitability and the American Law Institute, 27 STAN. L. REv. 879 (1975); Edward H. Rabin, Revolution in Residential Landlord-Tenant Law: Causes and
} 
simplicity, the critique of mandatory warranties on distributive grounds has outlived parallel accounts of economic reality. ${ }^{50}$ The critique is, in fact, so well established that Ben-Shahar and Bar-Gill need only hint at it. Their intended rhetorical effect is irony: a project heavily inspired by social justice may end up hurting the poor.

Their attack on the CESL then takes a methodological turn and targets what the authors perceive as the major flaw of the proposal: "More fundamentally, we argue that many of the mandatory arrangements lack an a-priori welfare-enhancing justification, because they are not responding to a systematic market failure or to a systematic redistributive problem." 51

Systematic market failures and systematic redistributive problems are the bread and butter of behavioral law and economics. ${ }^{52}$ This strand of scholarship, now spectacularly popular in legal academia, has at times thrown a monkey wrench into the works of rational choice economics by subverting the normative results of price theory, disrupting Chicagoan antitrust analysis, etc. ${ }^{53}$ In a comprehensive discussion of behavioral law and economics famously penned by Professors Jolls, Sunstein and Thaler, the example of mandatory contract rules is expressly invoked to show that the prediction of traditional law and economics (namely, price increase and regressive distribution flowing from the mandates) may be incorrect due to endowment effects or adverse selection. $^{54}$

Some commentators have viewed behavioral law and economics as an irritant, especially when based on questionable data. ${ }^{55}$ Accordingly, Ben-Shahar and Bar-Gill point the Commission in the only direction that in their view could justify its penchant for

Consequences, 69 CORNELL L. REv. 517 (1984) (defining this theory as “mainstream” in U.S. legal academia).

49 See Duncan Kennedy, Three Globalizations of Legal Thought, in THE NeW LAW AND ECONOMIC Development: A Critical Appraisal 19, 62 (David M. Trubek \& Alvaro Santos eds., 2006) (describing such vignettes).

${ }^{50}$ Nicola, supra note 1, at 139-44.

${ }^{51}$ Regulatory Techniques, supra note 15 , at 110.

${ }^{52}$ Christine Jolls et al., A Behavioral Approach to Law and Economics, 50 STAN. L. REV. 1471 (1998).

${ }^{53}$ See, e.g., Richard Epstein, The Dangerous Allure of Behavioral Economics: The Relationship Between Physical and Financial Products, TRUTH ON THE MARKET (Dec. 6, 2010), http://truthonthemarket.com/2010/12/06/richard-epstein-on-the-dangerous-allure-of-behavioral-economicsthe-relationship-between-physical-and-financial-products/; Douglas H. Ginsburg \& Joshua D. Wright, A Taxonomy of Behavioral Law and Economics Skepticism, TRUTH ON THE MARKET (Dec. 7, 2010), http://truthonthemarket.com/2010/12/07/ginsburg-and-wright-on-a-taxonomy-of-behavioral-law-andeconomics-skepticism/; Joshua D. Wright \& Douglas H. Ginsburg, Behavioral Law and Economics: Its Origins, Fatal Flaws, and Implications for Liberty, 106 Nw. U. L. REV. 1033 (2012).

${ }^{54}$ Jolls et al., supra note 52, at 1505.

${ }^{55}$ See Todd Zywicky, Op-Ed., In Elizabeth Warren We Trust?, WALL ST. J. (Sept. 30, 2010), available at http://online.wsj.com/article/SB10001424052748704523604575512060220672440.html. 
market regulation via contract law: a precise finding of asymmetric information, resulting from consumer biases and from seller conduct that caters to such biases. ${ }^{56}$ Professor BarGill has been particularly vocal on this point: "Only an in-depth inquiry into the specific market can identify a behavioral market failure-a persistent consumer mistake that causes substantial welfare loss. And only an in-depth market specific analysis can determine the optimal regulatory response to the identified market failure." ${ }^{\text {57 }}$

Until recently, this move would have caught the Commission somewhat unprepared. By design, the work of the Commission in the area of private-law harmonization is one of rapprochement of different socio-legal realities-a quintessential mélange, i.e., the opposite of contextualized empiricism. The European Union is a gigantic and variegated market, which encompasses very different cultures of both trade and consumption. Specificity is per se a challenge in this context. More fundamentally, the relative dearth of empirical legal studies in the European Union as compared to the United States is a function of a different methodological tradition. ${ }^{58}$ The historical prevalence of doctrinal and theoretical approaches to law has regularly stemmed the diffusion of legal realism and "law-and" movements. ${ }^{59}$ The American synergy of law and political science, based on the understanding of courts as essentially political institutions, has prompted interdisciplinary dialogue and popularized quantitative methods among lawyers. ${ }^{60}$ This has not been the case in Europe, where law-mostly studied at undergraduate level—has long remained insulated from other social sciences.

\footnotetext{
${ }^{56}$ See Regulatory Techniques, supra note 15, at 115 ("Mandatory rules are not bad by definition. They could be utilized efficiently when voluntary contracts cannot be relied upon to maximize social welfare ... . Consumers may fail to make good decisions either because of asymmetric information or because of imperfect rationality (and often the combination of the two) .... When sophisticated sellers face such naive consumers, the market equilibrium may include an inefficiently low level of consumer protection. This concern may justify an occasional protection[.]") (emphasis in original).

${ }^{57}$ Oren Bar-Gill \& Franco Ferrari, Informing Consumers about Themselves, 3 ERASMUS L. REV. 93 (2010); see also Oren Bar-Gill, Competition and Consumer Protection: A Behavioral Economics Account, in THE PRos AND CONS OF CONSUMER PROTECTION 12 (Swedish Competition Auth. 2012), available at http://www.konkurrensverket.se/upload/Filer/Trycksaker/Rapporter/Pros\&Cons/rapport_pros_and_cons_co nsumer_protection.pdf ("The severity of the behavioral market failure, and the ability of competition to mitigate the welfare costs of the behavioral market failure, will vary from market to market.”).

${ }^{58}$ See Peter Cane \& Herbert Kritzer, Introduction, in OXFORD HANDBOOK OF EMPIRICAL LEGAL RESEARCH 1, 5 (2010) (“[T]he common-law, English-speaking world has so far produced much more empirical legal research than the civil law world; and within the common law world, much more empirical research has been produced in the United States than anywhere else.”).

${ }^{59}$ HAZEL GENN ET AL., LAW IN THE REAL WORLD: IMPROVING OUR UNDERSTANDING OF HOW LAW WORKS 30 (2006). On the European resistance to legal realist approaches, see DUNCAN KENNEDY, A CRITIQUE OF ADJUDICATION [FIN DE SIÈCLE] (1997).

${ }^{60}$ See Cane \& Kritzer, supra note 58, at 5.
} 
Today empirical legal research is growing at a fast pace on European soil. In the particular field of consumer protection, qualitative and quantitative data are now piling up at impressive speed. ${ }^{61}$ But the particular burden of proof that Professors Ben-Shahar and Bar-Gill place on the Commission's shoulders still cannot be carried. The CESL is simply an effort to create convergence between decades-old national regulatory regimes: it does not invent any new pro-consumer device, and it cannot be held to retroactive evidentiary standards. The existing national rules for consumer contracts, on which the CESL project necessarily rests, may or may not have corrected pre-existing market failures. If they brought about measurable improvements, they did so without proof, because European consumer protection emerged from theory, ideology and inference, rather than from statistical evidence of fraud or accidents. Reverse engineering is not an option in social sciences, at least not in the context of multi-layered EU private-law systems. It is no longer possible to study systematic, sector-specific samples of market failures that may have been corrected, over time, by national legislation. The presence of somewhat different regulatory models within Europe can at times offer a laboratory for experiments, but the field of consumer protection has been, in many places, handled through judicial discretion leading to myriad unreported judgments. The paucity of hard data may be daunting. ${ }^{62}$ Where evidence is simply lacking, the burden of proof is difficult if not impossible to bear. If the future of consumer-friendly contract rules at the EU level depends on empirical findings of market irrationality, then the Commission should only tread virgin soil and focus on new markets. For consumer transactions already regulated by the states, EU harmonization — via optional instruments or any other tool—may be doomed to idiocy in the eyes of many U.S. scholars. Theoretical and pragmatic alternatives are possible, however, and should be explored.

\footnotetext{
${ }^{61}$ See Stephen Meili, Consumer Protection, in The Oxford HandBook of EmPIRICAl Legal Research 177, supra note 58. The emergence of EU networks of consumer protection bodies such as European Consumer Centres Network (ECC-Net) and the Consumer Protection Cooperation Network (CPC-Net, established with Regulation (EC) No. 2006/2004 of the European Parliament and Council of 27 October 2004 on cooperation between national authorities responsible for the enforcement of consumer protection laws) brings about regular reports rich in quantitative analyses of markets for consumer products. See, e.g., Online Cross-Border Mystery Shopping-State of the e-Union, EUROPEAN CONSUMER CENTRES NETWORK (ECC-NET) (2011), available at http://ec.europa.eu/consumers/ecc/docs/mystery_shopping_report_en.pdf. Most importantly, the Commission's Directorate-General for Health and Consumers (SANCO) spearheads a number of research projects, listed at http://ec.europa.eu/consumers/consumer_research/index_en.htm.

${ }^{62}$ A recent research paper submitted to the BEUC, a European Consumer Association, probes the difficulty of assembling information, from the perspective of legal enforcement, on collective consumer redress. The author of the report attempted to gather data on judicial proceedings, but admittedly hit a wall of unreported or under-reported court activity. The report also documents a list of other predictable obstacles to collection of data on consumer protection, including language barriers and a very uneven degree of collaboration from experts of different nationalities. Elodie Falla, Report to the European Consumer Organisation (BEUC): Powers of the Judge in Collective Redress Proceedings, at 10 (Feb. 2012), available at http://www.beuc.eu/BEUCNoFrame/Common/GetFile.asp?ID=42849\&mfd=off\&LogonName=Guesten.
} 


\section{The Burden of Proof: Origin AND Questions}

The now popular emphasis on context-specific empirical analysis stems, as observed, from the success of behavioral law and economics in U.S. legal academia. The relation between this discipline and neoclassical law and economics is unclear. Richard Posner notably posited that, in most cases, rational choice theory would be capable of incorporating any potential new insights of behavioral economics, ${ }^{63}$ as well as yielding superior prescriptions. The founders and promulgators of the new discipline, by contrast, have seen it as too big an improvement on neoclassical economics to be absorbed. These postures have not been reconciled as yet. The disagreement has recently taken markedly ideological tones. ${ }^{64}$

Professor Bar-Gill describes the relationship between the two disciplines is as follows:

Modern, neoclassical economics recognizes that even perfectly competitive markets can fail. The standard market failures are attributed to externalities and to asymmetric information. Behavioral economics adds a third market failure. The behavioral market failure, with its emphasis on misperception and bias, is a direct extension of the imperfect information problem . . . . The behavioral economics model, even more than its rational choice counterpart, is context dependent. ${ }^{65}$

Notice how this formulation sets up the two disciplines in hierarchical relation: both yield theoretical models; the behavioral model, however, is less stable and needs the support of empirical evidence. If context-specific data is lacking, the neoclassical model is by assumption superior and carries normative implications.

A prominent application of this methodological stance is provided by Bar-Gill himself in the context of what he names product-use information. Put very simply: with products like credit cards and cell-phones, manufacturers and distributors know much better than consumers how the product will be used or misused. By contrast, the

\footnotetext{
${ }^{63}$ Richard A. Posner, Rational Choice, Behavioral Economics, and the Law, 50 STAN. L. REV. 1551, 1552, 1557 (1998) (footnotes omitted) ("Some of the insights they ascribe to behavioral economics are already a part of economic analysis of law, which long ago abandoned the model of hyperrational, emotionless, unsocial, supremely egoistic, nonstrategic man (or woman) that [Jolls, Sunstein, and Thaler] in places appear to ascribe to it .... [E]conomists can model [weakness of will] in rational-choice terms. This shows that the mere existence of the irrationalities emphasized in behavioral economics need not derail rationalchoice economics.").

${ }^{64}$ See Ginsburg \& Wright supra note 53.

${ }^{65}$ Bar-Gill \& Ferrari, supra note 57, at 13-15.
} 
individual consumer underestimates - say-the chances of defaulting on his credit card deadlines, or exceeding the low-rate allowance of his cell-phone plan. ${ }^{66}$ Asymmetrical information leads the consumer to choices that do not maximize his welfare. He does end up defaulting and paying high late fees. ${ }^{67}$ He does use his cell-phone more often than he thought he would. He has contracted inefficiently. In a rational choice world, the predicament would be fixed along the following lines: the consumer would move on and switch to those competitive credit card companies that advertise the true likelihood of default and charge lower penalties, or to cell-phone brands that offer (higher) flat rates and do not charge steeply for each extra minute. But here is where behavioral insight makes a difference: the consumer is biased. The consumer would not be attracted by lower penalties or flat fees, because he would continue to misapprehend his consumption habits. Sellers would therefore have no incentive to tell him the truth about his statistically likely behavior. They would continue to compete with one another on usual grounds-low interest rates for credit cards; free-minute allowance on cell-phone plans; etc. ${ }^{68}$ This behavioral model makes the case for regulatory intervention, based as it is on the finding that only regulation would cure the identified asymmetrical information.

The model is strong, theoretically compelling, and absolutely intuitive. The behavioral scenario makes much more sense, at every level, than its rational-choice counterpart. It can be beautifully formalized, yields guidelines for action, and is very smart. Yet hard proof-not just plentiful anecdotal evidence of market failure-is required for it to prevail, prescriptively, over a simpler and altogether myopic model of the same market. This burden allocation has nothing to do with logic. There is ample evidence of regulatory failure, but also ample evidence to the contrary. ${ }^{69}$ The presumption against regulation stems, rather, from the particular intellectual and political experience of law and economics in America.

Laura Kalman relates the blooming of law and economics, symbolized by the publication of Richard Posner's "Economic Analysis of Law," to the 1970s' "taxpayers" revolt, the New Right and cultural conservatism." ${ }^{, 70}$ The conservative grip on law and

\footnotetext{
${ }^{66}$ Oren Bar-Gill \& Rebecca Stone, Mobile Misperceptions, 23 HARV. J.L. \& TECH. 49 (2009).

${ }^{67}$ Oren Bar-Gill \& Richard Epstein, Exchange: The Behavioral Economics of Consumer Contracts, 92 MinN. L. REV. 749, 771 (2008).

${ }^{68}$ Bar-Gill \& Ferrari, supra note 57, at 13 (“[I]mperfectly rational consumers generate biased demand. Competition forces sellers to cater to this biased demand. The result is what I call a behavioral market failure.").

${ }^{69}$ Shleifer, supra note 2, at 441-42.

${ }^{70}$ Laura Kalman, The Strange Career of Legal Liberalism 77 (1996); see also Fred Block, A Corporation with a Conscience?, 15(2) NEW LAB. F. 75 (2006), available at http://www.longviewinstitute.org/projects/moral/Fred\%20Block.pdf (noting the conservative turn in the corporate world that led to Ronald Reagan's election and to the triumph of market fundamentalism).
} 
economics, however, was not immediate. The field was initially occupied ${ }^{71}$ and then contested $^{72}$ by scholars motivated by distributive justice as much as by the aggregate efficiency of legal rules. The now dominant anti-regulation bias of neoclassical law and economics used to be just one among several economic models of any given market. ${ }^{73}$ It was shown, for instance, that habitability warranties - a significant interference in tenantlandlord relations-did not necessarily reduce the availability of affordable housing, neither in theory ${ }^{74}$ nor in practice. ${ }^{75}$ It was also shown that the alleged conflict between pro-consumer rules and efficiency was, in many cases, a false one. ${ }^{76}$ It is important to isolate this strand of legal scholarship of U.S. academia, to understand its genealogy, and to make it more visible in Europe, lest it be collapsed into the simple neoliberal, antiregulatory agendas. Contributions of this type stemmed from within neoclassical reasoning and had none of the defensive tone of new behavioral inquiries. Only a radical change in ideological climate can explain why, by the end of the 1990s, each challenge to rational choice assumptions has instead been cast in the narrowest of terms, as if it were the exception that proves the neoclassical rule. The reasons for this change exceed the scope of this paper. ${ }^{77}$ Here it suffices to note that the current anti-regulatory bias in the United States is a product of historical contingencies, and has no superior intellectual pedigree than more "statist" conceptions of the common good. ${ }^{78}$

The effect generated by the defensive, exceptionalist case for regulatory intervention is to burn otherwise viable bridges between EU law makers and U.S.-based legal scholars. Take, for instance, Ben-Shahar and Bar-Gill's condemning statement on

\footnotetext{
${ }^{71}$ See Guido CALABRESI, THE Cost OF ACCidEnTs (1970).

${ }^{72}$ See, e.g., Arthur Allen Leff, Economic Analysis of Law: Some Realism about Nominalism, 60 VA. L. REV. 451 (1974); Mark Kelman, Consumption Theory, Production Theory, and Ideology in the Coase Theorem, 52 S. CAL. L. REv. 669 (1979); Duncan Kennedy, Cost-Benefit Analysis of Entitlement Problems: A Critique, 33 STAN. L. REV. 387 (1981).

${ }^{73}$ Nicola, supra note 1.

${ }^{74}$ See Bruce Ackerman, Regulating Slum Housing Markets on Behalf of the Poor, 80 YALE L.J. 1093 (1971); see also Duncan Kennedy, The Effect of the Warranty of Habitability on Low Income Housing: “Milking” and Class Violence, 15 FlA. ST. U. L. REV 485 (1987); see also Richard S. Markovits, The Distributive Impact, Allocative Efficiency, and Overall Desirability of Ideal Housing Codes: Some Theoretical Clarifications, 89 HARV. L. REV. 1815 (1976).

${ }^{75}$ See Rabin, supra note 48 (adhering to the pass-along thesis in principle, but noticing that because of contingent characteristics of certain housing markets and because of institutional complexities, the prediction that the poor would find themselves unable to find housing did not materialize).

${ }^{76}$ See Richard Craswell, Passing on the Cost of Legal Rules: Efficiency and Distribution in Buyer-Seller Relationships, 43 STAN. L. REV. 361 (1991).

${ }^{77}$ Interpretations abound. Fred Block, for instance, has provided an account of why corporate actors in the United States have incrementally moved to the right of the American political spectrum. See Block, supra note 70 .

${ }^{78}$ See, e.g., Amartya Sen, Capitalism Beyond the Crisis, N.Y. ReV. OF Books (Mar. 26, 2009) (revisiting the pedigree of state intervention in economic theory).
} 
mandatory disclosure: “[T]he conventional European disclosure paradigm [adopted by the CESL] reproduces archaic templates that have consistently and irreparably failed.",79

This line loudly echoes Ben-Shahar's capillary review of traditional disclosure methods-especially disclosure to consumers via standardized forms, which has been proven to go entirely unnoticed, to be unnecessarily costly, and even to be misleading. ${ }^{80}$ It would be easy, therefore, to conclude that disclosure is yet another unnecessary burden imposed by the CESL upon traders, whose cost will eventually be passed along to consumers in the form of higher prices. Indeed, in an ideal and now popular neoclassical model, it is pointless to mandate disclosure, because an optimal amount of communication between sellers and buyers as to product features will be achieved through natural incentives and competitive forces among sellers, or (in the case of dangerous products) by means of common-law negligence standards selectively enforced in court. At first glance, the critique of the CESL's disclosure duties seems to reiterate this well-known refrain. A closer read, however, reveals other, more interesting opportunities for intellectual exchange. Quickly, the authors suggest the possibility of "new paradigm” disclosure duties: “-Very simple, aggregate metrics that consumers can easily understand and compare, like total cost of ownership or satisfaction ratings. Information that is designed and aimed to facilitate the work of sophisticated intermediaries."

This line hints at Bar-Gill's convincing plea for imposing disclosure duties on those categories of sellers who have hard data on consumers' use patterns, ${ }^{82}$ or at BenShahar's attempts to redefine the content of mandated disclosure in ways that really help consumers gain meaningful information. ${ }^{83}$ As always, these suggestions are cast in cautious and market-specific terms, ${ }^{84}$ but the clear-if brief-message is regulatory in nature. If consumers are not well served by boilerplate warnings on sellers' forms, it is time to invent better ways for keeping them informed. This is a far cry from the neoclassical approach to private law, which notoriously rejects the very idea of redistribution through legal rules and deems the goal of aiding the disadvantaged better

\footnotetext{
${ }^{79}$ Regulatory Techniques, supra note 15 , at 110.

${ }^{80}$ Ben-Shahar \& Schneider, supra note 43.

${ }^{81}$ Regulatory Techniques, supra note 15, at 119.

${ }^{82}$ Bar-Gill \& Stone, supra note 66.

${ }^{83}$ Ben-Shahar \& Schneider, supra note 43, at 732.

${ }^{84}$ See Regulatory Techniques, supra note 15, at 119 ("If there is a place for more targeted and simplified disclosures, it is not in a general sales law like the CESL, but rather in market specific laws and regulations.”).
} 
served, if necessary, through public law tools such as taxation. ${ }^{85}$ As observed above, the neoclassical approach to private law generally tends to disfavor the reduction of private autonomy. It continues to have an extraordinary grip both in the United States and in Europe, tied as it is to neoliberal ideology. ${ }^{86}$ European contract law, however, hosts alternative ideological trends that have recently gained scholarly ground, while in the United States alternative voices are currently feeble. European academics traveling to Chicago expect to find resistance to the very idea of redistribution through private law. Against this background, the cautious pro-regulatory stance of these neoclassically trained authors is especially remarkable and instructive. It is important to isolate their principled endorsement of regulation through private law from their skeptical view of two dimensions of the CESL: its thin empirical foundations and its ability to achieve meaningful redistribution via an opt-in instrument. ${ }^{87}$

When this is done, it becomes clear that behavioral law and economics can provide important support for regulatory projects inspired by social justice ideals. And in an intellectual environment that places a lighter burden of proof on regulators, behavioral insights may really carry the day.

\section{PRIVATE LAW, SOCIAL JUSTICE AND REDISTRIBUTION}

A distributive justice question pervades, silently, the entire Bar-Gill and BenShahar paper. Are the pro-consumer rules contemplated by the CESL proposal truly progressive? This is a question that traditional law and economics scholars tend to deem only rhetorical and to answer, intuitively, in the negative. But through the lens of behavioral economists, the question becomes real and has no predetermined answer: given what is known of a specific market, who will really benefit or suffer from a changed regime of private autonomy? Professor Bernstein's skepticism about our understanding of Europe's myriad socio-economic realities contributes to the empiricists' anxiety.

This quintessentially realist question has become crucial, among progressive EU intellectuals, in the aftermath of a set of decisions by the Court of Justice of the EU, all

\footnotetext{
${ }^{85}$ See, e.g., Louis Kaplow \& Steven Shavell, Why the Legal System is less Efficient than the Income Tax in Redistributing Income, 23 J. LEGAL STUD. 667 (1994); contra Christine Jolls, Behavioral Economics Analysis of Redistributive Legal Rules, 51 VAND. L. REV. 1653 (1998).

${ }^{86}$ Collin Crouch, The Strange Non-Death of NeOliberalism (2011).

${ }^{87}$ See Regulatory Techniques, supra note 15, at 125 ("The more the optional law pulls the second lever of consumer protection, and sets it beyond the levels existing in most Member States, the less often the proposed law would be chosen and less uniformity would ensue.”).
} 
concerning significant wage differentials among workers in old and new EU Member States. ${ }^{88}$ In the especially iconic judgment known as Viking, the Court was faced with a conflict between industrial action and market freedoms-in this case, the freedom of Viking, a ferry operator based in Finland, to change its vessels' flag from Finnish to Estonian, so as to evade Finnish union control over its workers' wages. Viking's decision to reflag had prompted collective action both within Finland and internationally, and Viking, invoking its freedom of establishment, had requested that imminent strikes be enjoined. The Court held that the right to strike could not be exercised disproportionately, and that international collective action intended to impede Viking's freedom to reflag could not be justified under EU law. ${ }^{89}$ This decision acknowledged that low wages and weak labor rights are a source of comparative advantage for new Member States' businesses. The 2004-2007 enlargement of the Union would necessarily bring into question the status of labor rights in Nordic and western Member States.

The case generated much anxiety in pro-labor circles. To be sure, nobody on the left of the political spectrum would object to the idea of redistributing some wealth from healthier economies to the periphery of the Union. What was - and continues to beupsetting is the fact that the particular redistribution enabled by decisions of the Viking type moves wealth away from the workers of State A to the worse-off nationals of State $\mathrm{B}$, and at the same time allows the employers of State A to stay in profitable business. In so far as, within State A, employers as a class are better off than workers, the type of redistribution enabled by Viking is starkly regressive. ${ }^{90}$ Viking's deregulatory effects, seemingly virtuous on distributive grounds, fail the realist test in a multi-state context.

The pro-labor tone of this critique should not prevent us from noticing how similar it is to questions raised in the United States by law and economics scholars in matters of regulated private autonomy. Just like Viking's endorsement of economic freedom for businesses, the imposition of regulatory constraints upon sellers may seem inspired by good intentions, but given the socio-economic asymmetry of present-day Europe, it may actually steer wealth away from the wrong place. Imagine, for instance, the following simple scenario: as a result of uniform sales rules, sellers in State B become

${ }^{88}$ Case C-346/06, Rüffert v. Land Niedersachsen, 2008 E.C.R. I-1989; Case C-319/06, Comm'n v. Luxembourg, 2008 E.C.R. I-4323; Case C-341/05, Laval un Partneri Ltd. v. Byggnadsarbetareforbundet, 2007 E.C.R. I-11767; Case C-438/05, Int'l Transp. Workers' Fed'n v. Viking Line ABP, 2007 E.C.R. I10779 [hereinafter Viking].

${ }^{89}$ Viking, supra note 88, para. 88 (" $[I] n$ relation to the collective action seeking to ensure the implementation of the policy in question pursued by ITF[, an international association of seamen], it must be emphasised that, to the extent that that policy results in shipowners being prevented from registering their vessels in a State other than that of which the beneficial owners of those vessels are nationals, the restrictions on freedom of establishment resulting from such action cannot be objectively justified.”).

${ }^{90}$ Alexander Somek, From Workers to Migrants, From Distributive Justice to Inclusion: Exploring the Changing Social Democratic Imagination, 18 EUR. L.J. 711 (2012). 
subject to the same degree of costs as sellers in State A, but their ability to pass these costs on to consumers is much lower: their brands-given consumer biases-are less appealing; if they charged higher prices, consumers would not buy from them. Their margin of profit is thereby reduced and would only be made up by increased sales volume if consumers truly valued the increase in post-sale remedies caused by the new law (an effect that cannot be taken for granted). In the end, consumers everywhere may be better off, but the sellers who have contributed to consumers' overall welfare are those of State B only. In so far as they are, by definition, of lower economic status compared to sellers in State A, the transfer of wealth that derives from sales law uniformity is of the regressive type. ${ }^{91}$

To be sure, this type of inquiry has often been used for deregulatory purposes, ${ }^{92}$ but this should not lead us to discard its entire methodology. There are excellent examples of distributive analysis informed by empirical findings and applied to regulatory constraints upon private autonomy. ${ }^{93}$ The analysis may well yield proregulatory prescriptions or sound fine-tuning advice. When there is no predetermined answer, it may be foolish to withhold the question. And the relative scarcity of empirical studies in the European legal tradition is no reason to disregard the implications of intuitive models.

Just as we duly question, in theory and in practice, the distributive effects of such pro-market rulings as Viking, we should investigate the distributive impact of proconsumer rules. The plea for pragmatic impact assessment, which is central to the American critique, should not be ignored in Europe either. Europe may not be able, at present, to produce the sort of fine-grained empirical analysis that has come to be required in behavioral economics circles. Nonetheless, Europe cannot and should not continue to ignore, by design, the impact on the ground of its private-law

\footnotetext{
${ }^{91}$ For a rare discussion of such issues, see Antonina Bakardjieva Engelbrekt, The Impact of EU Enlargement on Private Law Governance in Central and Eastern Europe: The Case of Consumer Protection, in MAKING EUROPEAN PRIVATE LAW 98 (Fabrizio Cafaggi \& Horatia Muir-Watt eds., 2010).

${ }^{92}$ See Jonathan Klick \& Thomas Stratmann, Subsidizing Addiction: Do State Health Insurance Mandates Increase Alcohol Consumption?, 35 J. Legal STUD. 175 (2006). Note that Jonathan Klick, Professor of Law at the University of Pennsylvania Law School, holds the part-time Erasmus Chair of Empirical Legal Studies at Erasmus Law School, in the heart of Europe.

${ }^{93}$ Christine Jolls looked at another form of regulation of private exchange-namely, the ADA'a mandate upon employers to accommodate workers with disabilities. Jolls produced a refined model of post-ADA employment, corroborated by data. This study by no means concluded that the prohibition of disability discrimination hurt the very people it meant to protect. On the contrary, it found that the relevant mandates were (at least in part) desirable on redistributive grounds, and that neoclassical predictions of doom in ADA matters were largely misplaced. See Christine Jolls, Accommodation Mandates, 53 STAN. L. REV. 223 (2000).
} 
harmonization. ${ }^{94}$ To be sure, even if the outcome of the inquiry reveals regressive effects at any level, the result need not be (pace Richard Epstein) the "tamping down" of the whole pro-consumer agenda. ${ }^{95}$ It may very well be that EU-wide contract rules should continue to reflect uniform values such as the protection of weaker parties or the sanctity of post-sale remedies. It would be important, however, to include in the architecture of reform elements of compensation or reparation for those who stand to lose disproportionately from an otherwise desirable regulatory intervention.

The template for such reparations is to be found in the rich economic and philosophical foundations of systems theory, postcolonial studies and development economics. Just like the harmonization of private-law rules, the stipulation of worldwide labor and environmental standards may impose heavier burdens on developing countries. It is important to be cognizant of such burdens in designing uniform rules, not because standards should be eliminated, but rather because they should be embedded in comprehensive and compensatory trade regimes. ${ }^{96}$

\section{CUSTOMIZING BEHAVIORAL INQUIRY}

It is time to turn to the possibilities that behavioral law and economics-a discipline in its infancy in Europe-could open up for European law and policy makers. The very spirit of empiricism demands that we develop modes of exploration that the U.S. camp of behavioral studies has not yet elaborated, and that may be particularly suited for the project of regulating EU markets. It is also important to remember that thick qualitative evidence may be, in certain pockets of Europe, the best that we can assemble. As observed above, in an intellectual environment less prone to neoclassical bias, a combination of credible theoretical models and detectable corroborating data should suffice to rebut the presumption that markets can self-heal.

Predictably, behavioral economics has already gained official status within SANCO, the Directorate General of the Commission responsible for health and consumer protection. A link on its website takes visitors to a page that explains the methodology of

\footnotetext{
${ }^{94}$ See, for clever examples of such inquiries, Alexander Somek's analyisis of Viking (supra note 88), and Fernanda Nicola's discussion of Bidar in Invisible Cities in Europe, 35 FoRDHAM InT'L L.J. 1282 (2012).

${ }^{95}$ Epstein, supra note 13, at 210.

${ }^{96}$ For example, a conceptual model for such compensatory mechanisms can be found in generalized systems of preferences (GSP) conditioned on compliance with common international labor standards (CLS). See Michael J. Trebilcock et Al., The Regulation of International Trade 738-40 (4th ed. 2013).
} 
behavioral economics. ${ }^{97}$ On the same page, there are links to market-specific studies, such as online shopping for household appliances, energy, or meat, and data keep coming. ${ }^{98}$

Unsurprisingly, in those data the Commission finds systematic proof that its action is badly needed towards the goal of facilitating cross-border trade: a recent issue of the Consumer Markets Scoreboard reveals, for instance, that e-commerce in the European Union "remains largely domestic despite the clear potential in terms of choice and savings across borders." 99

Notice, however, that the Commission's findings generalize broadly. Buying online domestically may indicate two very different things. In states where local brands enjoy a high reputation, domestic on-line sales simply mean that consumers continue to cling to such brands and to prefer them over cheaper imports. In states with poorer socioeconomic standing, whose local brands are insignificant and whose traders sell mostly through physical channels of distribution, buying online within state borders may indicate a preference for foreign brands, made locally available by foreign commercial presence. ${ }^{100}$ All these circumstances - the superiority of western brands in the eyes of European consumers, the relative ability or willingness to embrace on-line trade as opposed to local shopping in different parts of the EU, the one-way move of Western traders and brands to Eastern Europe, and the ability to segment markets thanks to consumer biases $^{101}$ —are hardly visible, and so remain a vastly underestimated source of additional economic imbalance. ${ }^{102}$

The result of this extensive blind spot in the Commission's analysis of EU markets is somewhat paradoxical. The making of uniform private-law rules for the entire European market—seemingly a regulatory project-shares a basic assumption of laissez

${ }^{97}$ Behavioral Economics, EUROPEAN COMMISSION, http://ec.europa.eu/consumers/behavioural_economics/index_en.htm (last visited on Dec. 7, 2012).

${ }^{98}$ Health \& Consumers: Consumer Research, EUROPEAN COMMISSION, http://ec.europa.eu/consumers/consumer_research/index_en.htm (last visited on Dec. 7, 2012).

${ }^{99}$ Health \& Consumers: Consumer Conditions Scoreboard, 7th Edition (May 2012), EUROPEAN Commission, available at http://ec.europa.eu/consumers/consumer_research/editions/cms7_en.htm.

${ }^{100}$ Jared Salter, From Karl Marx to Trademarks, BRANDCHANNEL (June 19, 2006), http://www.brandchannel.com/brand_speak.asp?bs_id=140. Important insights in consumer-side discrimination can be found in Janja Hojnik, Free Movement of Goods in a Labyrinth: Can Buy Irish Survive the Crises? 49 Common MKT. L. ReV. 291 (2012).

${ }^{101}$ See Ian Ayres et al., To Insure Prejudice: Racial Disparities in Taxicab Tipping, 114 YALE L.J. 1613 (2005) (investigating patterns of consumer-side discrimination).

${ }^{102}$ Kukovec, supra note 16, at 5 (“[M]any goods, not just luxury goods, are cheaper in 'Eastern' Europe than in 'Western' Europe. Western European companies are able to segment markets and dump goods in Eastern Europe, where the price elasticity of demand is higher due to lower purchasing power, thus undercutting Eastern European competition. [. . . Goods] dumping has enormous potential to harm the periphery's industry and level of employment.”). 
faire, namely an indifference to the socio-economic disparities of all market actors. One can only hope that the progressive refinement of market analysis may bring to the fore both intended and unintended consequences of private-law harmonization.

Some authors would question a priori the relevance of this style of investigation to the making of EU private law. Europe, it has been argued, needs uniform rules that embrace the value of consumer protection, care for the weaker parties, and are structured so as to curb the abuses of large manufacturers against individual and isolated buyers. If these are the stated rules of private interaction, the argument continues, these values will "trickle up" and eventually lead to a socially sensitive vision of EU governance. ${ }^{103}$ The code should set the tone for an overall decent European polity, even though the uniformity of private-law rules across Europe may pose inconveniences of other type. Besides - the argument often goes - the very embrace of economic jargon is tainted with pro-efficiency bias. It frames political discussions in utilitarian terms and eventually falls prey to neoliberal agendas. ${ }^{104}$ The revival of the work of Karl Polanyi in contemporary EU private-law literature reveals this fear of contagion from exposure to economic jargon. ${ }^{105}$ Whither markets? Wouldn't the project of European integration rather benefit from a suspension of market assumptions? The exception carved in primary EU law for services of general economic interest is a most dramatic example of resistance to the tyranny of commodification. The wave of political activism against the draft Bolkenstein directive on cross-border services had the same flavor-a desire to turn the tables away from neoliberalism and counteract the gravitational pull of economic logic. ${ }^{106}$

This chasm between "market talk" and social justice parlance is the result of a historically contingent appropriation of economic discourse by a particular type of intellectual and political worldview. Given this ideological quasi-monopoly, it is natural for social justice advocates to experience alienation when exposed to the mantra of markets' principled efficiencies. It is, however, a scholarly and strategic mistake to take the chasm at face value. The Chicago conference reveals the presence of a lively and solid strand of law and economics inquiry that goes beyond neoclassical economics and asks the very same questions Europe should ask itself. The proposed CESL, just as the

\footnotetext{
${ }^{103}$ See, e.g., ColLiNS, supra note 28; Kennedy, supra note 28, at 7.

${ }^{104}$ See, e.g., Ugo Mattei, A Theory of Imperial Law: A Study on U.S. Hegemony and the Latin Resistance, 10 IND. J. GLOBAL LEGAL STUD. 383 (2003).

105 See Michelle Everson \& Christian Joerges, Reconfiguring the Politics-Law Relationship in the Integration through Conflicts-Law Constitutionalism, 18 EUR. L.J. 644 (2012); see also Marija Bartl, Legitimacy and European Private Law (2012) (unpublished doctoral thesis, European University Institute) (on file with author).

${ }^{106}$ See Amandine Crespy, When "Bolkestein" is Trapped by the French Anti-liberal Discourse: A Discursive-Institutionalist Account of Preference Formation in the Realm of European Union Multi-Level Politics, 17 J. Eur. PuB. POL’y 1253 (2010).
} 
entire project of EU law harmonization, is based either on legal theory or on qualitatively poor evidence-large-scale data that really miss the point of market-based inequalities. The socio-economic divergence between different pockets of Europe is dramatically visible, yet the narrative that uniform market rules bring benefits to all remains mostly uncontested in Brussels.

It is important to note, in closing, that these pages are not meant to resist the continuing harmonization of market rules as a general matter. ${ }^{107}$ Depending on political circumstances or expressive aspirations, further steps towards uniformity may prove desirable or unavoidable. What needs to change is the win-win narrative that accompanies such projects within the Commission. When a uniform set of rules is imposed upon a constellation of diverse constituencies, discrepancies may worsen rather than be cured. If that is the case, then the costs of uniformity must be made explicit and private-law reform re-embedded in corrective and compensatory mechanisms. It is therefore crucial to subject proposed reforms to distributive scrutiny and to identify likely losers before the game begins. Generic arguments in favor of consumers, with no insight into east-west, north-south, or class dynamics, leave much to be desired in Chicago, and should not be deemed sufficient in Brussels either. In forging ahead with its harmonization project, Europe may be dodging numbers at its peril. Polanyi's most valuable insight in the present context is that dramatic wealth disparities have resulted from precise planning and specific rules that seemed, in principle, benign. ${ }^{108}$ As the EU project brings us to reconsider the rules of our markets, our focus must stay sharp on the wealth they generate, destroy, or transfer.

\footnotetext{
${ }^{107}$ Cf. Christian Joerges \& Christoph Schmid, Towards Proceduralization of Private Law in the European Multi-Level System, in TowARDS A EUROPEAN Civil CodE, supra note 3, at 277, 295 ("The [Commission's strategy of full harmonization] is at odds with the socio-economic diversity which persists, and is even deepening, in Europe. In view of this diversity, the imposition of uniform rules on the balancing of market development and consumer demand do not make economic sense. They also risk the destruction of the social fabric of markets and consumption which remains ... in important respects characterized by national contexts.”).

${ }^{108}$ See Karl Polanyi, The Great Transformation: The Political and Economic Origins of OuR TiME (1944) (especially ch. 6, The Self-Regulating Market and the Fictitious Commodities: Labor, Land, and Money).
} 